\title{
Analysis of a single-institution cohort of patients with Felty's syndrome and T-cell large granular lymphocytic leukemia in the setting of rheumatoid arthritis
}

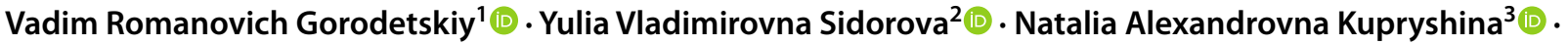 \\ Vladimir Ivanovich Vasilyev ${ }^{4}$ (D) Natalya Alexandrovna Probatova ${ }^{5}$ (i) $\cdot$ Natalya Valerievna Ryzhikova ${ }^{2}$ (i) \\ Andrey Borisovich Sudarikov ${ }^{2}$ (D)
}

Received: 28 August 2020 / Accepted: 16 November 2020 / Published online: 5 December 2020

(c) The Author(s) 2020

\begin{abstract}
T-cell large granular lymphocytic leukemia (T-LGLL) is a lymphoproliferative disorder characterized by a persistent increase in the number of large granular lymphocytes (LGLs), neutropenia, and splenomegaly. Clinical manifestations of T-LGLL in the setting of rheumatoid arthritis (RA) are often identical to those in which one would suspect Felty's syndrome (FS). These disorders are distinguished by the presence of T-cell clonality, which is present in T-LGLL but not in FS. Mutations in the signal transducer and activator of transcription 3 (STAT3) and 5b (STAT5b) genes can be used as molecular markers of T-LGLL, but their prevalence in FS is unknown.

Eighty-one patients with RA and unexplained neutropenia or/and an increase in the number of LGLs above $2 \times 10^{9} / \mathrm{L}$ were stratified into RA-associated T-LGLL $(N=56)$ or FS $(N=25)$ groups based on the presence or absence of T-cell clonality. STAT3 and STAT5 $b$ gene mutations were assessed in each group by means of allele-specific polymerase chain reaction assays. Clinical, immunological, laboratory data and the results of immunophenotyping of blood and bone marrow lymphocytes were also evaluated.

Mutations of the STAT3 gene and an increase in the number of LGLs above $2 \times 10^{9} / \mathrm{L}$ were detected in RA-associated T-LGLL, but not in FS (39\% vs 0\% and 21\% vs 0\%, respectively). Mutations in the STAT5b gene were not observed in either group. Expression of $\mathrm{CD} 57, \mathrm{CD} 16$, and $\mathrm{CD}^{-/ \mathrm{dim}}$ on $\mathrm{CD}^{+} \mathrm{CD}^{+} \mathrm{T}$-lymphocytes was observed in both RA-associated T-LGLL and FS.

STAT3 gene mutations or LGL counts over $2 \times 10^{9} / \mathrm{L}$ in RA patients are indicative of T-LGLL.
\end{abstract}

Keywords Felty's syndrome $\cdot$ Large granular lymphocyte leukemia $\cdot$ Rheumatoid arthritis $\cdot$ STAT3 $\cdot$ STAT5b · Comorbidity

\section{Introduction}

Felty's syndrome (FS) is a clinical diagnosis that is suspected in patients with rheumatoid arthritis (RA), neutropenia, and splenomegaly. The persistence of unexplained neutrophil counts of less than $1.5-2.0 \times 10^{9} / \mathrm{L}$ is a mandatory

Supplementary Information The online version contains supplementary material available at https://doi.org/10.1007/s0029 6-020-04757-4.

Vadim Romanovich Gorodetskiy

gorodetskiyblood@mail.ru

Extended author information available on the last page of the article criterion for diagnosing FS. Although splenomegaly is a component of the triad for defining FS, currently, it is not an absolute requirement for diagnosis $[1,2]$. The vast majority of patients with FS have high titers of both rheumatoid factor (RF) and anti-cyclic citrullinated peptide (anti-CCP) antibodies [3,4]. FS usually develops, on average, 12 years after RA presentation; the mean age of the patients is 60 years, with a female-to-male ratio of 1.5:1 [5]. There is no specific diagnostic test to confirm the presence of FS; therefore, the identification of FS is essentially based on an exception diagnosis.

T-cell large granular lymphocytic leukemia (T-LGLL) is a rare chronic lymphoproliferative disorder characterized by the expansion of clonal, immunophenotypically 
distinct, large granular lymphocytes (LGLs). In most cases, T-LGLL is characterized by an immunophenotype of cytotoxic T-lymphocytes $\left(\mathrm{CD}^{+} / \mathrm{CD}^{+}\right)$that co-express the natural killer (NK)-cell lineage-associated antigens CD16 and/or CD57, and diminished or absent expression of the pan-T-cell markers CD5 and/or CD7 [6, 7]. Approximately $15 \%$ of patients with T-LGLL have RA [8, 9]; on the contrary, the clonal expansion of LGLs was detected in $3.6 \%$ of patients with RA [10]. Human leukocyte antigen (HLA)-RD4 is detected in approximately $90 \%$ of patients with T-LGLL and concurrent RA, but in only $33 \%$ of patients with T-LGLL without RA (similar to that in the general population); this strongly supports an immunogenetic link between T-LGLL and RA [11]. T-LGLL is usually diagnosed 10-20 years after the manifestation of RA [5], although both conditions may present simultaneously, and T-LGLL may also precede the clinical manifestations of RA by several years [12-15]. A typical manifestation of T-LGLL includes neutropenia and splenomegaly, which are detected in up to $84 \%$ and $50 \%$ of patients, respectively [16]. Historically, a definitive diagnosis of LGLL can be made if the LGL count is persistently greater than $2 \times 10^{9} / \mathrm{L}$ in peripheral blood for more than 6 months [ 16 , 17]. However, T-LGLL can currently be diagnosed if the LGL count exceeds 0.4 or $0.5 \times 10^{9} / \mathrm{L}$, provided that a clonal $\mathrm{T}$-cell population is found with an appropriate clinical context (cytopenia and/or an autoimmune disease) [18-20]. Bone marrow involvement is present in at least $75 \%$ of T-LGLL cases, though it is often subtle and difficult to detect morphologically. Although specific criteria have been proposed for the diagnosis of T-LGLL in bone marrow sections using immunohistochemistry [21], they do not seem to be sufficiently specific to distinguish T-LGLL from FS [5].

Currently, T-LGLL and FS can be distinguished by T-cell clonality, which can be determined by assessing the T-cell receptor (TCR) gene rearrangements present in T-LGLL, but not in FS [5, 13, 22]. In addition, recent studies have identified activating somatic mutations in the signal transducer and activator of transcription 3 (STAT3) gene in $27-72 \%$ of patients with T-LGLL [23-26] and in the signal transducer and activator of transcription 5b (STAT5b) gene in $2 \%$ of patients with T-LGLL [27]. However, the prevalence of $S T A T 3$ and $S T A T 5 b$ mutations in FS is unknown.

In this study, we stratified 81 patients with RA and unexplained neutropenia or/and an increase in the number of LGLs into two groups (RA-associated T-LGLL or FS) based on the presence or absence of T-cell clonality; we then examined STAT3 and STAT5 $b$ gene mutations in both groups. We also assessed the clinical, immunological, and laboratory data of the patients, as well as the results of immunophenotyping of blood and bone marrow lymphocytes of those with
FS and RA-associated T-LGLL to identify characteristics that would allow for their differential diagnosis.

\section{Patients and methods}

This retrospective study included 81 adult patients who met the following two criteria: (i) RA diagnosed according to the 2010 American College of Rheumatology/European League Against Rheumatism criteria [28]; (ii) neutropenia (absolute neutrophil counts less than $1.5 \times 10^{9} / \mathrm{L}$ ) or/ and an elevated LGL count exceeding $2 \times 10^{9} / \mathrm{L}$ in peripheral blood. Patients with drug-induced neutropenia were excluded from the study.

Tissue samples available for the studies are shown in Table 1. Peripheral blood smears were re-examined for LGL counting in 64 cases. Bone marrow aspiration with differentiated cell counts was performed in 53 cases; a bone marrow biopsy was also performed in 45 of these. The collected clinical data included patient age, sex, presence of splenomegaly, RA duration, titers of RF, anti-CCP antibodies, antibodies against mutated citrullinated vimentin (anti-MCV), antinuclear antibodies (ANA), erosive arthritis, and associated Sjögren syndrome (SS).

\section{Flow cytometric analysis}

A four-color flow cytometric analysis was performed on specimens of peripheral blood alone (51 cases), peripheral blood and bone marrow (17 cases), or bone marrow alone (four cases). Lymphocytes were gated using CD45 versus side-scatter dot-plots. Cells were stained with a panel of fluorescence-labeled monoclonal antibodies, including CD3, CD4, CD5, CD7, CD8, CD16, CD19, CD57, TCR- $\alpha / \beta$, and TCR- $\gamma / \delta$. Flow cytometric analysis was performed on a BD FACSCanto ${ }^{\mathrm{TM}}$ II (Becton Dickinson, San Jose, CA, USA) system using FCS Express version 3 (De Novo Software, Los Angeles, CA) software.

\section{Immunohistochemical studies}

Immunohistochemical studies were carried out in 38 of 45 cases using sections of decalcified paraffin-embedded bone marrow biopsy specimens. The following antibodies were used at the dilutions suggested by the manufacturers: CD3 (polyclonal, Dako), CD4 (clone 4B12, Dako), CD8 (clone C8/144B, Dako), CD20 (clone L26, Dako), CD56 (clone 123C3, Dako), CD57 (clone TB01, Dako), granzyme B (clone GrB-7, Dako), and T-cell restricted intracellular antigen 1 (TIA-1) (clone 2G9, Immunotech, France). After dewaxing and heat-induced antigen 
Table 1 Tissue samples available for the studies

\begin{tabular}{|c|c|c|c|c|}
\hline & & $\mathrm{N}(\mathrm{FS})$ & $\begin{array}{l}\mathrm{N} \text { (RA } \\
\text { with } \\
\text { T-LGLL) }\end{array}$ & $\Sigma$ \\
\hline \multicolumn{2}{|l|}{ PB smears for LGL counting } & 17 & 47 & 64 \\
\hline \multicolumn{2}{|l|}{ BM aspirates for differentiated cell count } & 13 & 40 & 53 \\
\hline \multicolumn{2}{|l|}{ BM histological examination } & 11 & 34 & 45 \\
\hline \multicolumn{2}{|l|}{ BM immunohistochemical study } & 10 & 28 & 38 \\
\hline \multirow[t]{6}{*}{ T-cell clonality } & PB & 14 & 30 & 44 \\
\hline & $\mathrm{BM}$ & 1 & 0 & 1 \\
\hline & $\mathrm{PB}+\mathrm{BM}$ & 8 & 15 & 23 \\
\hline & $\mathrm{PB}+$ Spleen & 1 & 5 & 6 \\
\hline & $\mathrm{BM}+$ Spleen & 0 & 2 & 2 \\
\hline & $\mathrm{PB}+\mathrm{BM}+$ Spleen & 1 & 4 & 5 \\
\hline \multirow[t]{7}{*}{ STAT3 and $S T A T 5 b$ gene mutations } & $\mathrm{PB}$ & 19 & 39 & 58 \\
\hline & $\mathrm{BM}$ & 1 & 1 & 2 \\
\hline & $\mathrm{PB}+\mathrm{BM}$ & 2 & 5 & 7 \\
\hline & PB + Spleen & 2 & 7 & 9 \\
\hline & $\mathrm{BM}+$ Spleen & 0 & 1 & 1 \\
\hline & Spleen & 0 & 3 & 3 \\
\hline & ND & 1 & 0 & 1 \\
\hline \multirow[t]{3}{*}{ Flow cytometric analysis } & $\mathrm{PB}$ & 15 & 36 & 51 \\
\hline & $\mathrm{BM}$ & 1 & 3 & 4 \\
\hline & $\mathrm{PB}+\mathrm{BM}$ & 2 & 15 & 17 \\
\hline
\end{tabular}

$N$ available number of samples, $F S$ Felty's syndrome, $T$ - $L G L L$ T-cell large granular lymphocytic leukemia, $P B$ peripheral blood, $B M$ bone marrow, $L G L$ large granular lymphocytes, $R A$ rheumatoid arthritis, $N D$ no data

retrieval, immunostaining was performed on an Autostainer Link 48 (Dako, Denmark) according to the manufacturer's instructions. All immunostained samples were counterstained with hematoxylin.

\section{Evaluation of STAT3 and STAT5b gene mutations, and T-cell clonality}

STAT3 and STAT5b gene mutations, and T-cell clonality were examined using genomic DNA extracted from blood, bone marrow, and spleen tissue samples (Table 1). The evaluation of $\mathrm{T}$-cell clonality based on the rearrangements of the TCR gamma $(\mathrm{V} \gamma-\mathrm{J} \gamma)$ and TCR beta $(\mathrm{V} \beta-\mathrm{J} \beta, \mathrm{D} \beta-\mathrm{J} \beta)$ genes was performed in all cases. In addition, TCR delta

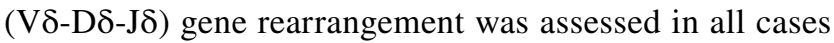
with suspected $\gamma \delta$ T-cell proliferation. T-cell clonality assays were performed according to the BIOMED-2 standardized protocol [29]. Polymerase chain reaction (PCR) amplification was carried out using an automated DNA Engine thermocycler (BioRad, Hercules, USA), and fragments were detected using an ABI PRISM 3130 Genetic Analyzer (Applied Biosystems, Foster City, CA); the data were analyzed using GeneMapper software version 4.0 (Applied Biosystems, Foster City, CA).
Allele-specific (AS) TaqMan Real-Time PCR assays were developed to determine the somatic point mutations in the STAT3 (p.Y640F; p.N647I; p.D661V; p.D661Y; p.D661H; p.D661N) and STAT5b (p.N642H) genes. DNA (200-400 $\mathrm{ng}$ ) was added to $25 \mu \mathrm{L}$ of the reaction mixture containing $10 \mathrm{pmol}$ of WT (wild type)-specific or MT (mutated type)-specific forward primer, 10 pmol of common reverse primer, and $7.5 \mathrm{pmol}$ of the fluorescent probe. AS-PCR was then performed in triplicate (three WT \& three MT) using a StepOne Real-Time PCR System (Applied Biosystems, USA). PCR conditions included preliminary denaturation at $95{ }^{\circ} \mathrm{C}$ for $5 \mathrm{~min}$, followed by 45 cycles at $95^{\circ} \mathrm{C}$ for $30 \mathrm{~s}, 62^{\circ} \mathrm{C}$ for $30 \mathrm{~s}$, and $72{ }^{\circ} \mathrm{C}$ for $30 \mathrm{~s}$. A mixture of DNA from healthy donors was used as a negative control. Samples with mutations confirmed by Sanger sequencing were used as positive controls. The primer and probe sequences are shown in Supplement 1. Patients with T-cell clonality were assigned to the T-LGLL group; in the absence of T-cell clonality, they were assigned to the FS group.

\section{Statistical analysis}

Statistical analyses were performed using R software (version 3.5). Descriptive statistics are presented as numbers 
and percentages for categorical data, and as medians and ranges for continuous data. Differences in the distributions of categorical variables among patients with FS and RA with T-LGLL were assessed by two-sided proportion test with continuity correction and $95 \%$ confidence interval; continuous variables were assessed by the Mann-Whitney $U$ test. $P$ values $\leq 0.05$ were considered statistically significant.

\section{Results}

Of the $81 \mathrm{RA}$ patients included in this study, neutropenia of less than $1.5 \times 10^{9} / \mathrm{L}$ was detected in 78 cases. In seven of these 78 cases, there was also an increase in the absolute number of circulating LGLs exceeding $2 \times 10^{9} / \mathrm{L}$. According to the absence or presence of T-cell clonality, these 78 patients were stratified into two groups, either the FS (25 patients) or the RA-associated T-LGLL (53 patients) group, respectively. In three out of 81 patients, neutropenia was absent. However, there was an increase in the number of T-LGLs in blood exceeding $2 \times 10^{9} / \mathrm{L}$ and T-cell clonality, which allowed classifying as T-LGLL. Thus, this study included 25 patients with FS and 56 patients with RA-associated T-LGLL.

\section{FS cohort}

The clinical and biological characteristics of the 25 patients with FS are presented in Table 2 and Supplement 2. Nineteen $(76 \%)$ patients were female and eight $(32 \%)$ had concomitant SS. The median age at FS diagnosis was 56 years (range 30-79 years). The median duration of RA prior to FS diagnosis was 7 years (range $0-35$ years). Erosive arthritis at the time of FS diagnosis was detected in 17 (77\%) of 22 patients. RF, anti-CCP and anti-MCV antibodies were positive in $23(92 \%)$ of 25 , in $23(96 \%)$ of 24 , and in $12(100 \%)$ of 12 patients, respectively. In two RF-negative patients,

Table 2 Characteristics of patients with Felty's syndrome and RA with T-LGL leukemia

\begin{tabular}{|c|c|c|c|c|c|}
\hline \multirow[t]{2}{*}{ Clinical and biological features } & \multirow[t]{2}{*}{ Felty's syndrome } & \multirow[t]{2}{*}{ RA with T-LGLL } & \multirow[t]{2}{*}{$P \leq 0.05$} & \multicolumn{2}{|l|}{$95 \% \mathrm{CI}$} \\
\hline & & & & Min & $\operatorname{Max}$ \\
\hline Number of patients & 25 & 56 & & & \\
\hline No. female/no. male & $19 / 6$ & $41 / 15$ & & & \\
\hline *Age $(y)$, median (range) & $56(30-79)$ & $58.5(27-76)$ & & & \\
\hline${ }^{\#}$ Duration (y) of RA, median (range) & $7(0-35)$ & $6(0-36)$ & & & \\
\hline Erosive arthritis & $77 \%(17 / 22)$ & $69 \%(35 / 51)$ & & & \\
\hline RF positive & $92 \%(23 / 25)$ & $82 \%(46 / 56)$ & & & \\
\hline Anti-CCP positive & $96 \%(23 / 24)$ & $88 \%(49 / 56)$ & & & \\
\hline Anti-MCV positive & $100 \%(12 / 12)$ & $81 \%(34 / 42)$ & & & \\
\hline Splenomegaly & $83 \%(19 / 23)$ & $56 \%(31 / 55)$ & 0.05 & 0.029 & 0.496 \\
\hline Associated Sjögren's syndrome & $32 \%(8 / 25)$ & $20 \%(11 / 56)$ & & & \\
\hline STAT3 mutation positive & $0 \%(0 / 24)$ & $39 \%(22 / 56)$ & 0.0009 & -0.551 & -0.235 \\
\hline$S T A T 5 b$ mutation positive & $0 \%(0 / 24)$ & $0 \%(0 / 56)$ & & & \\
\hline \multicolumn{6}{|l|}{ Hematologic features } \\
\hline Leukocytes $\left(\times 10^{9} / \mathrm{L}\right)$, median (range) & $1.900(1.100-3.400)$ & $2.650(0.700-10.200)$ & 0.023 & & \\
\hline Neutrophils $\left(\times 10^{9} / \mathrm{L}\right)$, median (range) & $0.496(0.052-1.224)$ & $0.495(0.000-3.468)$ & & & \\
\hline Neutrophils $\left(\times 10^{9} / \mathrm{L}\right)<0.5$ & $52 \%(13 / 25)$ & $52 \%(29 / 56)$ & & & \\
\hline Lymphocyte $\left(\times 10^{9} / \mathrm{L}\right)$, median (range) & $1.092(0.420-2.320)$ & $1.752(0.490-7.452)$ & 0.0005 & & \\
\hline Lymphocyte $\left(\times 10^{9} / \mathrm{L}\right)>4.0$ & $0 \%(0 / 25)$ & $14 \%(8 / 56)$ & 0.05 & -0.263 & -0.022 \\
\hline LGLs $\left(\times 10^{9} / \mathrm{L}\right)$, median (range) & $0.418(0.117-1.036)$ & $0.850(0.252-6.552)$ & 0.0004 & & \\
\hline LGLs $\left(\times 10^{9} / \mathrm{L}\right)>0.4$ & $59 \%(10 / 17)$ & $85 \%(40 / 47)$ & & & \\
\hline LGLs $\left(\times 10^{9} / \mathrm{L}\right)>2.0$ & $0 \%(0 / 17)$ & $21 \%(10 / 47)$ & 0.05 & -0.370 & -0.056 \\
\hline Percent of lymphocytes in the BM & $12.4(3.8-18.4)$ & $22.0(5.2-80.3)$ & 0.0025 & & \\
\hline \multicolumn{6}{|c|}{ Immunophenotypic characteristics of cytotoxic $(\mathrm{CD} 3+\mathrm{CD} 8+) \mathrm{T}$-lymphocytes } \\
\hline $\mathrm{CD} 7^{+}$ & $59 \%(10 / 17)$ & $92 \%(49 / 53)$ & 0.003 & -0.620 & -0.053 \\
\hline $\mathrm{CD}^{-/ \mathrm{dim}}$ & $71 \%(12 / 17)$ & $93 \%(50 / 54)$ & 0.05 & -0.486 & 0.046 \\
\hline $\mathrm{CD} 16^{+}$ & $7 \%(1 / 15)$ & $24 \%(12 / 51)$ & & & \\
\hline
\end{tabular}

* at FS or T-LGLL diagnosis; \# before the diagnosis of FS or T-LGLL, RA rheumatoid arthritis, FS Felty's syndrome, $T$ - $L G L L$ T-cell large granular lymphocytic leukemia, $B M$ bone marrow, $L G L s$ large granular lymphocytes 
Fig. 1 The results of the ANA test in the patients with FS and RA with T-LGLL

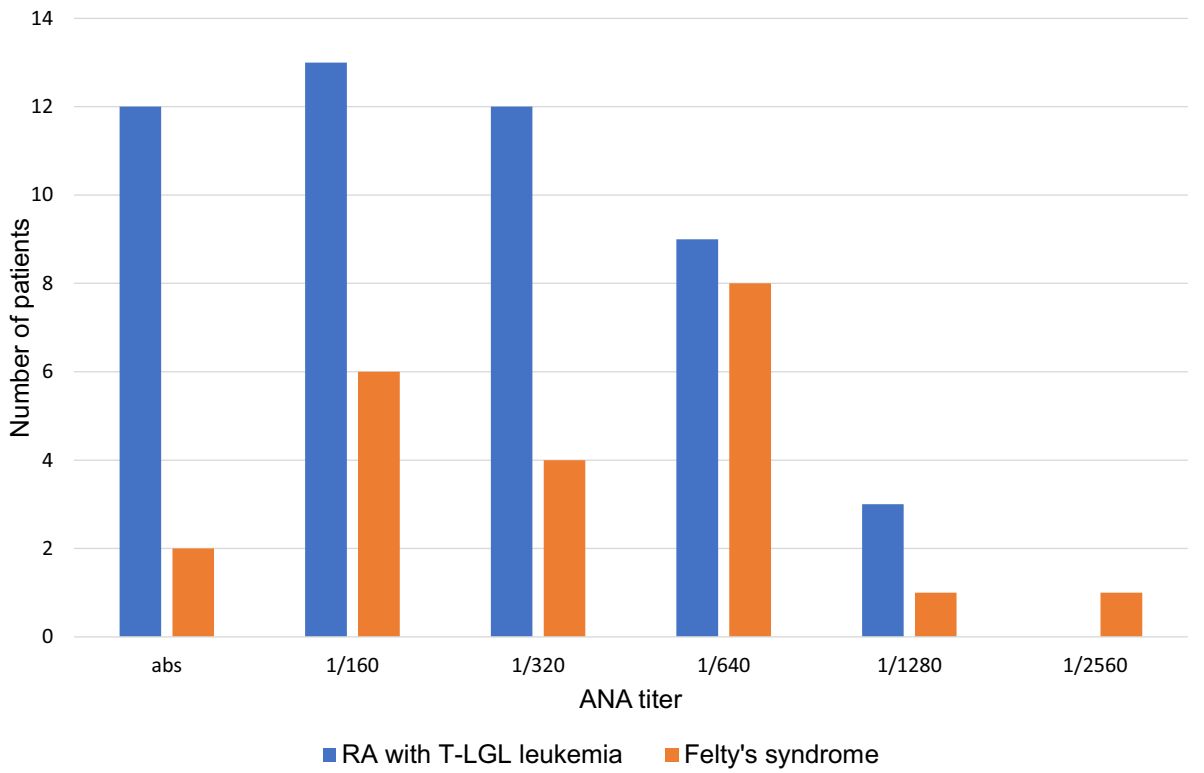

the anti-CCP and anti-MCV titers were highly positive. The ANA test was positive in $20(91 \%)$ of 22 patients (Fig. 1).

The median neutrophil count was $0.496 \times 10^{9} / \mathrm{L}$, with a range of $0.052-1224.0 \times 10^{9} / \mathrm{L}$. Absolute neutrophil counts less than $0.5 \times 10^{9} / \mathrm{L}$ were observed in $13(52 \%)$ of 25 patients. The absolute number of lymphocytes ranged from 0.42 to $2.32 \times 10^{9} / \mathrm{L}$, with a median of $1.092 \times 10^{9} / \mathrm{L}$. LGL counts in the blood exceeding $0.4 \times 10^{9} / \mathrm{L}$ were observed in $10(59 \%)$ of 17 cases, but the counts did not exceed $2.0 \times 10^{9} / \mathrm{L}$ in any of the cases.

The results of the flow cytometric immunophenotyping of cytotoxic $\left(\mathrm{CD}^{+} \mathrm{CD}^{+}\right)$T-lymphocytes are summarized in
Table 2. Absent or diminished expression of CD5 (CD5 $\left.{ }^{-/ \mathrm{dim}}\right)$ was present in $12(71 \%)$ of 17 cases. CD57 expression was found in 10 (59\%) of 17 cases, while CD16 expression was found in only one $(7 \%)$ of 15 cases.

Bone marrow aspirate samples were available in 13 patients with FS. In all cases, there were no signs of myelodysplasia. The number of lymphocytes in the bone marrow did not exceed the upper limit of the adult norm (23.8\% lymphocytes) in any case, and they comprised between 3.8 and $18.4 \%$ of all nucleated cells. Bone marrow aspirate differential cell counts showed a significant reduction in the number of segmented neutrophils in 10 of 13 patients; in one other
Fig. 2 Examples of bone marrow findings in the patients with FS. a Patient \#9. Immunoperoxidase staining for granzyme B highlights numerous granzyme $\mathrm{B}^{+}$lymphocytes; original magnification: $\times 400$. A cluster of more than 10 cells is shown in the inset with an original magnification of $\times 1000$. b Patient \#24. Immunoperoxidase staining for CD8 demonstrates a linear array of intravascular $\mathrm{CD}^{+}$lymphocytes; original magnification: $\times 1000$

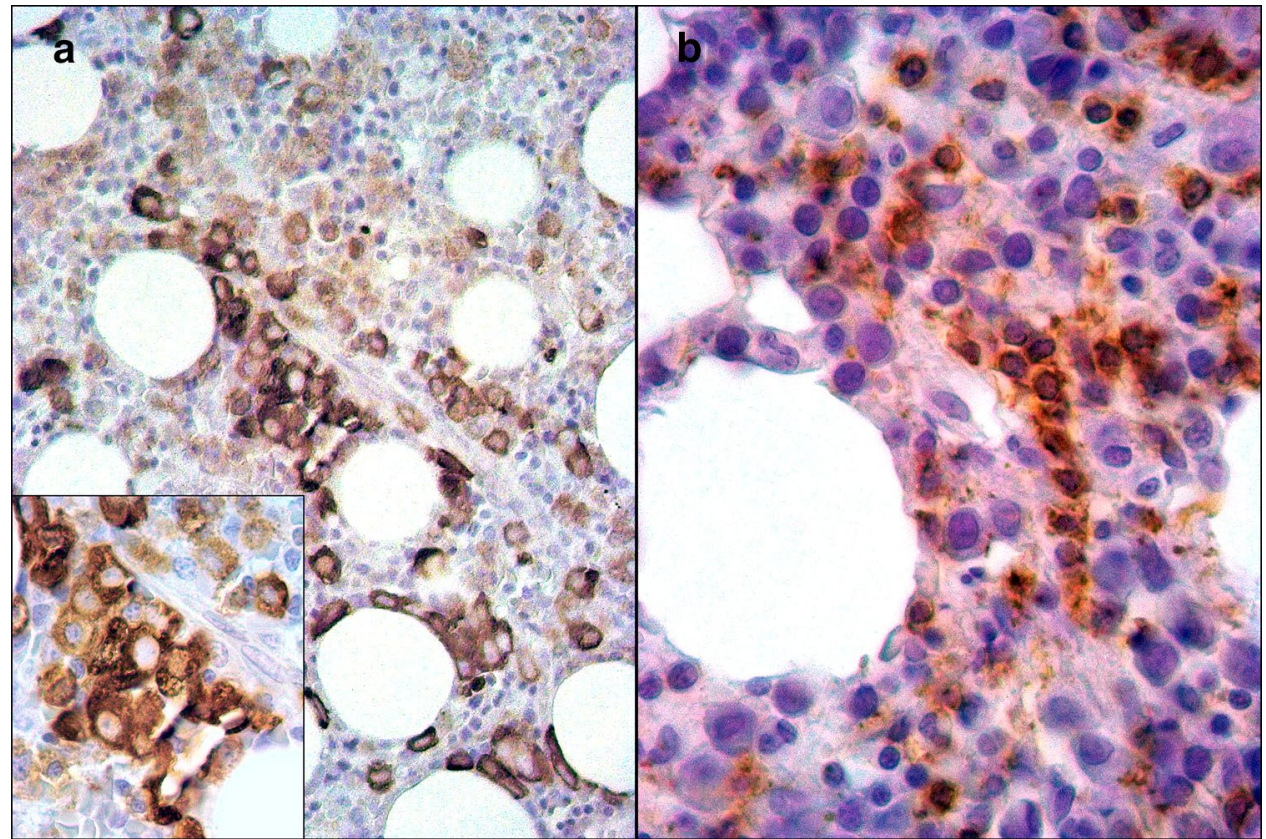


patient, there was a reduction in the band and segmented neutrophils. However, in two patients, the bone marrow aspirate differential count was normal, despite a decrease in the number of neutrophils in the blood. Bone marrow immunohistochemistry showed interstitial clusters and/or linear arrays of intravascular $\mathrm{CD}^{+} /$granzyme $\mathrm{B}^{+}$lymphocytes in two of 10 cases (Fig. 2). Splenomegaly was observed in 19 (83\%) of 23 patients. Mutations in the STAT3 and STAT5b genes were not detected in any of the 24 patients with FS.

\section{RA with T-LGLL cohort}

The clinical and biological characteristics of the 56 patients with RA-associated T-LGLL are presented in Table 2 and Supplement 3.

In a cohort of patients with RA-associated T-LGLL, 41 (73\%) patients were female, and the median age at the time of T-LGLL diagnosis was 58.5 years (range 27-36 years). SS associated with RA was diagnosed in $11(20 \%)$ patients. The median duration of RA prior to a T-LGLL diagnosis was 6 years (range 0-36 years). Erosive arthritis at the time of T-LGLL diagnosis was detected in $35(69 \%)$ of 51 patients. RF was positive in 46 (82\%) of 56 patients and was negative in $10(18 \%)$ cases. Anti-CCP and anti-MCV were present in $49(88 \%)$ of 56 patients and in $34(81 \%)$ of 42 patients, respectively. Four patients had erosive seronegative RA. The ANA test was positive in 37 (76\%) of 49 patients (Fig. 1).

The absolute number of neutrophils in peripheral blood ranged from 0 to $3.468 \times 10^{9} / \mathrm{L}$, with a median of $0.495 \times 10^{9} / \mathrm{L}$; in $29(52 \%)$ of 56 patients, the absolute neutrophil count was less than $0.5 \times 10^{9} / \mathrm{L}$. The absolute number of lymphocytes in peripheral blood ranged from 0.490 to $7.452 \times 10^{9} / \mathrm{L}$, with a median of $1.752 \times 10^{9} / \mathrm{L}$; in eight (14\%) of 56 patients, the absolute lymphocyte count exceeded $4 \times 10^{9} / \mathrm{L}$. An absolute number of LGLs exceeding $0.4 \times 10^{9} / \mathrm{L}$ was observed in $40(85 \%)$ of 47 cases; it exceeded $2.0 \times 10^{9} / \mathrm{L}$ in 10 of these cases.

The results of the flow cytometric immunophenotyping of lymphocytes of patients with RA-associated T-LGLL are shown in Table 2 . The most commonly identified phenotypic abnormalities on cytotoxic $\left(\mathrm{CD}^{+} \mathrm{CD}^{+}\right)$T-lymphocytes were $\mathrm{CD}_{5} 7^{+}$[in $49(92 \%)$ of 53 cases] and $\mathrm{CD}^{-/ \mathrm{dim}}$ [in 50 (93\%) of 54 cases]. The expression of CD16 was found in $12(24 \%)$ of 51 cases.

Bone marrow aspirate samples were available from 40 patients with T-LGLL. Dysplastic changes in myeloid cell lineages and megakaryocytes, as well as a marked decrease of erythroid cell lineages, were observed in case \#41. Multilineage dysplasia was found in case \#49. The number of lymphocytes in the bone marrow ranged from 5.2 to $80.3 \%$ of nucleated cells and exceeded the upper limit of the adult normal level in 15 (60\%) of 25 cases. Bone marrow aspirate differential counts showed a significant reduction in segmented neutrophils in 15 patients, segmented and band neutrophils in three patients, segmented neutrophils, band neutrophils, and neutrophilic metamyelocytes in 11 patients, and segmented neutrophils, band neutrophils, neutrophilic metamyelocytes, and neutrophilic myelocytes in five patients. In six patients, the bone marrow aspirate differential count was normal, despite the presence of neutropenia in five of these patients. In 21 (75\%) of 28 cases, immunohistochemical studies of the bone marrow showed interstitially distributed clusters of at least eight $\mathrm{CD} 8^{+}$or TIA- $1^{+}$lymphocytes or clusters of at least six granzyme $\mathrm{B}^{+}$lymphocytes and/or linear arrays of intravascular $\mathrm{CD} 8^{+}$, TIA- $1^{+}$, or granzyme $\mathrm{B}^{+}$lymphocytes corresponding to the involvement of T-LGLL. Splenomegaly was observed in 31 (56\%) of 55 patients. STAT3 gene mutations were found in 22 (39\%) of 56 patients with RA-associated T-LGLL. The p.Y640F mutation was present in nine $(41 \%)$ cases, followed by p.N647I and p.D661Y in six (27\%) cases each, and p.D661V in one (5\%) case (Supplement 3). No cases with more than one mutation were identified. A somatic p.N642H mutation in STAT5b gene was not found in any of the 56 patients with RA-associated T-LGLL.

\section{Discussion}

The most typical presenting features of T-LGLL include neutropenia, an increase in the number of LGLs in the blood, and splenomegaly. In the setting of RA, cases of T-LGLL with low number of LGLs in the peripheral blood and with neutropenia are indistinguishable from FS; therefore, they represent a diagnostic challenge. At present, discriminating between FS and T-LGLL in the setting of RA often depends on the result of an assessment of T-cell clonality, which has well-known gray areas in the interpretation [30]. Moreover, there has been considerable discussion regarding the significance of dominant T-cell clones as a hallmark of T-cell malignancy because small populations of clonally expanded T-LGLs are revealed in healthy individuals and in situations associated with an exuberantly reactive response [31-35].

Mutations in the STAT3 and STAT5 $b$ genes can be used as molecular markers for T-LGLL diagnostics [36], but their prevalence in FS and their diagnostic value for the differential diagnosis between FS and RA-associated T-LGLL remain unclear. We did not find STAT3 mutations in any of the 24 patients with FS, as opposed to 22 of the 56 patients with RA-associated T-LGLL ( $0 \%$ versus $39 \%, P=0.00086$ ). Savola et al. examined STAT3 and STAT5 $b$ mutations in 14 patients with RA and neutropenia [37]. Similar to our patient cohort, they did not find any STAT5b mutations. However, in contrast to our results, they did identify STAT3 mutations in six $(43 \%)$ of 14 patients. We believe that the difference 
between the outcomes reported by Savola et al. and our study can be attributed to the different methods of assessing $\mathrm{T}$-cell clonality and the patient selection criteria. We tested T-cell clonality based on the rearrangement of gamma, beta, and, in cases with the $\gamma \delta$ T-cell phenotype, also delta chain encoding genes by a PCR-based assay, whereas Savola et al. studied the clonality of T-cells by flow cytometry using a $\mathrm{V} \beta$ kit that covered only $70 \%$ of the $\mathrm{V} \beta$ T-cell repertoire. In addition, in contrast to Savola et al., we did not include patients with T-cell clonality in the FS group.

Differences in sex, the age at diagnosis, the duration of $\mathrm{RA}$, the incidence of erosive arthritis, RF, anti-CCP, and anti-MCV positivity, and SS diagnosis between the groups with FS and RA-associated T-LGLL were statistically insignificant in our sample. Splenomegaly ranged from massive to detectable based solely on abdominal ultrasound and was more common in patients with FS than in those with RAassociated T-LGLL ( $83 \%$ versus $56 \%, P=0.05$ ).

In our patients with FS, the increase of absolute number of LGLs in the peripheral blood over $0.4 \times 10^{9} / \mathrm{L}$ was detected in $10(59 \%)$ of 17 cases, but it did not exceed $2.0 \times 10^{9} / \mathrm{L}$ in any case. In the group of patients with RAassociated T-LGLL, 40 (85\%) of 47 patients had more than $0.4 \times 10^{9} / \mathrm{L}$ circulating LGLs in the blood and, in contrast to patients with FS, 10 (21\%) of these 47 patients had an increase of LGLs in peripheral blood of more than $2.0 \times 10^{9} / \mathrm{L}$. A statistically significant difference was found between the patients with FS and RA-associated T-LGLL in terms of the percentage of lymphocytes in the bone marrow. The distribution of FS and RA-associated T-LGLL cases according to the number of LGLs in the peripheral blood

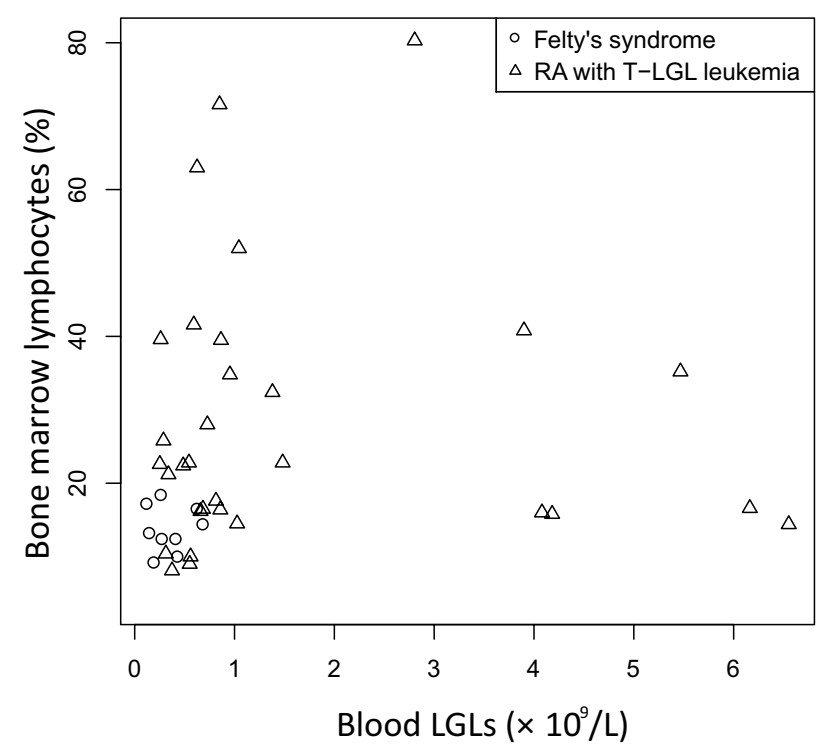

Fig. 3 The distribution of FS and RA-associated T-LGLL cases according to the number of LGLs in the peripheral blood in relation to the percentage of lymphocytes in the bone marrow in relation to the percentage of lymphocytes in the bone marrow is presented in Fig. 3. The bone marrow aspirate differential counts showed increased number of lymphocytes in $60 \%$ of patients with RA-associated T-LGLL, but no one in the FS group.

Flow cytometric immunophenotyping plays an important role in the diagnosis of T-LGLL; however, the value of this method in the differential diagnosis of T-LGLL and the reactive expansion of LGLs in FS has not been established. Statistically significant differences were found in the expression of the CD57 antigen and the aberrant (diminished or absent) expression of CD5 between the FS and RA-associated T-LGLL groups. In contrast, no statistically significant difference was found in the expression of CD16.

Morice et al. suggested that clusters of six or more granzyme $\mathrm{B}^{+}$lymphocytes or sinusoidal linear arrays of $\mathrm{CD}^{+}$, TIA- $1^{+}$, or granzyme $\mathrm{B}^{+}$lymphocytes are specific for T-LGLL, but not for non-clonal T-LGL disorders [21]. However, in our cohort, as in the Burks et al. study [5], there were patients with a specific pattern of bone marrow infiltration by cytotoxic T-lymphocytes that is characteristic of T-LGLL, but in the absence of T-cell clonality (Fig. 2). Further data accumulation is necessary to facilitate the interpretation of these results.

The clinical features of RA in the setting of T-LGLL have not been thoroughly characterized. According to ProchorecSobieszek et al., the severity of arthritis can vary [38]. It should be noted that several seropositive patients without a history of inflammatory arthritis had erosions and typical radiographic changes for $\mathrm{RA}$.

The duration from the diagnosis of RA until the development of FS or T-LGLL in our cohort was shorter than that reported by others [5]. All 25 patients with FS were seropositive $\left(\mathrm{RF}^{+} /\right.$anti-CCP $/$anti- $\mathrm{MCV}^{+}$or $\mathrm{RF}^{-} /$anti-CCP ${ }^{+} /$ anti- $\mathrm{MCV}^{+}$), whereas in the RA group with T-LGLL, four of 56 patients had erosive, seronegative RA.

The percentage of patients in our cohort with T-LGLL with an increase in blood lymphocyte counts exceeding $4.0 \times 10^{9} / \mathrm{L}$ was $14 \%$, which is comparable to a study by Zhu et al. [39]. However, in earlier works, the authors reported a much higher percentage of such patients at $74 \%$ [16] and $51 \%$ [8]. This is probably because of changes in the criteria for T-LGLL diagnosis over time.

\section{Limitations}

Since our study was retrospective, some data were not available. In addition, we used the AS TaqMan real-time PCR assay to detect somatic point mutations in the STAT3 and $S T A T 5 b$ genes using a set of primers for the most common mutations in the two genes. Even though this approach provides much higher sensitivity than Sanger sequencing, some 
rare mutations that were not covered by the developed primers could not be identified.

It should be noted that in six cases (all with massive splenomegaly), a study of the spleen detected T-cell clonality that was absent in the blood and/or bone marrow. In addition, out of the 28 patients for whom both blood and bone marrow samples were tested, two (7\%) displayed T-cell clonality only in the bone marrow and not in the blood. Given the above, it cannot be ruled out that among the 14 patients who were classified as having FS based on the absence of T-cell clonality only in the peripheral blood, there were still patients with T-cell clonality in the spleen and/or bone marrow.

\section{Conclusion}

We did not detect STAT3 gene mutations in any of the 24 patients with FS, whereas mutations were found in 22 (39\%) of 56 patients with RA-associated T-LGLL. An increase in the absolute number of LGLs in the blood above $2 \times 10^{9} / \mathrm{L}$ was also a specific characteristic of RA-associated T-LGLL that was not found in the FS group in our study. In contrast, typical immunophenotypic markers of T-LGLL were also found in the polyclonal expansion of cytotoxic T-lymphocytes in the setting of RA. Although further data are required, our results suggest that the currently used criteria for immunohistochemical examination of the bone marrow do not seem to be able to definitively distinguish FS from T-LGLL in the setting of RA.

Acknowledgements We would like to thank Editage (www.edita ge.com) for English language editing and A. Firyulin for expert help in preparing the figures.

Author contributions VRG collected samples, collected clinical patient data, analyzed data, took part in study design, performed the statistical analysis, and wrote, edited, and reviewed the manuscript. YVS collected samples, performed molecular studies, took part in study design, substantially contributed to the interpretation of the data, edited and reviewed the manuscript. NAK performed flow cytometric analysis, took part in study design, substantially contributed to the interpretation of the data, edited and reviewed the manuscript. VIV collected clinical patient data, took part in study design, substantially contributed to the interpretation of the data, edited and reviewed the manuscript. NAP performed histopathological and immunohistochemical examinations, took part in study design, substantially contributed to the interpretation of the data, edited and reviewed the manuscript. NVR collected samples, performed molecular studies, took part in study design, substantially contributed to the interpretation of the data, edited and reviewed the manuscript. ABS took part in study design, substantially contributed to the interpretation of the data, edited and reviewed the manuscript. All authors approved the final manuscript as submitted and agree to be accountable for all aspects of the work.

Funding This study did not receive any funding support.
Availability of data and materials All data generated or analyzed during this study are included in this article.

\section{Compliance with ethical standards}

Conflict of interest The authors declare that they have no conflicts of interest regarding the publication of this study.

Ethics approval The study was approved by the V.A. Nasonova Research Institute of Rheumatology Ethics Committee (protocol \#17 on the 20-02-2020) and was conducted in accordance with the Declaration of Helsinki of 1975, as revised in 2008.

Consent to participate Written informed consent was given by all participants included in the study.

Open Access This article is licensed under a Creative Commons Attribution 4.0 International License, which permits use, sharing, adaptation, distribution and reproduction in any medium or format, as long as you give appropriate credit to the original author(s) and the source, provide a link to the Creative Commons licence, and indicate if changes were made. The images or other third party material in this article are included in the article's Creative Commons licence, unless indicated otherwise in a credit line to the material. If material is not included in the article's Creative Commons licence and your intended use is not permitted by statutory regulation or exceeds the permitted use, you will need to obtain permission directly from the copyright holder. To view a copy of this licence, visit http://creativecommons.org/licenses/by/4.0/.

\section{References}

1. Spivak JL (1977) Felty's syndrome: an analytical review. Johns Hopkins Med J 141:156-162

2. Campion G, Maddison PJ, Goulding N, James I, Ahern MJ, Watt I, Sansom D (1990) The Felty syndrome: a case-matched study of clinical manifestations and outcome, serologic features, and immunogenetic associations. Medicine (Baltimore) 69:69-80

3. Goldberg J, Pinals RS (1980) Felty syndrome. Semin Arthritis Rheum 10:52-65. https://doi.org/10.1016/0049-0172(80)90014-1

4. Turesson C, Jacobsson LT, Sturfelt G, Matteson EL, Mathsson L, Rönnelid J (2007) Rheumatoid factor and antibodies to cyclic citrullinated peptides are associated with severe extra-articular manifestations in rheumatoid arthritis. Ann Rheum Dis 66:59-64. https://doi.org/10.1136/ard.2006.054445

5. Burks EJ, Loughran TP Jr (2006) Pathogenesis of neutropenia in large granular lymphocyte leukemia and Felty syndrome. Blood Rev 20:245-266. https://doi.org/10.1016/j.blre.2006.01.003

6. Morice WG, Kurtin PJ, Leibson PJ, Tefferi A, Hanson CA (2003) Demonstration of aberrant T-cell and natural killer-cell antigen expression in all cases of granular lymphocytic leukaemia. Br J Haematol 120:1026-1036. https://doi.org/10.104 6/j.1365-2141.2003.04201.x

7. Lundell R, Hartung L, Hill S, Perkins SL, Bahler DW (2005) T-cell large granular lymphocyte leukemias have multiple phenotypic abnormalities involving pan-T-cell antigens and receptors for MHC molecules. Am J Clin Pathol 124:937-946

8. Bareau B, Rey J, Hamidou M, Donadieu J, Morcet J, Reman O, Schleinitz N, Tournilhac O, Roussel M, Fest T, Lamy T (2010) Analysis of a French cohort of patients with large granular lymphocyte leukemia: a report on 229 cases. Haematologica 95:15341541. https://doi.org/10.3324/haematol.2009.018481 
9. Sanikommu SR, Clemente MJ, Chomczynski P, Afable MG 2nd, Jerez A, Thota S, Patel B, Hirsch C, Nazha A, Desamito J, Lichtin A, Pohlman B, Sekeres MA, Radivoyevitch T, Maciejewski JP (2018) Clinical features and treatment outcomes in large granular lymphocytic leukemia (LGLL). Leuk Lymphoma 59:416-422. https://doi.org/10.1080/10428194.2017.1339880

10. Schwaneck EC, Renner R, Junker L, Einsele H, Gadeholt O, Geissinger E, Kleinert S, Gernert M, Tony HP, Schmalzing M (2018) Prevalence and characteristics of persistent clonal T cell large granular lymphocyte expansions in rheumatoid arthritis: a comprehensive analysis of 529 patients. Arthritis Rheumatol 70:1914-1922. https://doi.org/10.1002/art.40654

11. Starkebaum G, Loughran TP Jr, Gaur LK, Davis P, Nepom BS (1997) Immunogenetic similarities between patients with Felty's syndrome and those with clonal expansions of large granular lymphocytes in rheumatoid arthritis. Arthritis Rheum 40:624-626. https://doi.org/10.1002/art.1780400406

12. Lamy T, Loughran TP Jr (2003) Clinical features of large granular lymphocyte leukemia. Semin Hematol 40:185-195. https://doi. org/10.1016/s0037-1963(03)00133-1

13. Shah A, Diehl LF, St Clair EW (2009) T cell large granular lymphocyte leukemia associated with rheumatoid arthritis and neutropenia. Clin Immunol 132:145-152. https://doi.org/10.1016/j. clim.2009.03.515

14. Schrenk KG, Krokowski M, Feller AC, Bernhard V, Mügge LO, Oelzner P, Wolf G, Hochhaus A, Neumann T (2013) Clonal T-LGL population mimicking leukemia in Felty's syndrome-part of a continuous spectrum of T-LGL proliferations? Ann Hematol 92:985-987. https://doi.org/10.1007/s00277-012-1649-1

15. Hasanov E, Fard EV, Puravath A, Johnston JS, Peerbhai S, RojasHernandez CM (2018) T-cell large granular lymphocytic leukaemia in the context of rheumatoid arthritis. Lancet 392:1071. https ://doi.org/10.1016/S0140-6736(18)32208-6

16. Loughran TP Jr (1993) Clonal diseases of large granular lymphocytes. Blood 82:1-14

17. Semenzato G, Pandolfi F, Chisesi T, De Rossi G, Pizzolo G, Zambello R, Trentin L, Agostini C, Dini E, Vespignani M, Cafaro A, Pasqualetti D, Giubellino MC, Migone N, Foa R (1987) The lymphoproliferative disease of granular lymphocytes. A heterogeneous disorder ranging from indolent to aggressive conditions. Cancer 60:2971-2978. https://doi.org/10.1002/1097-0142(19871 215)60:12\%3c2971::aid-cncr2820601220\%3e3.0.co;2-o

18. Semenzato G, Zambello R, Starkebaum G, Oshimi K, Loughran TP Jr (1997) The lymphoproliferative disease of granular lymphocytes: updated criteria for diagnosis. Blood 89:256-260

19. Moignet A, Lamy $T$ (2018) Latest advances in the diagnosis and treatment of large granular lymphocytic leukemia. Am Soc Clin Oncol Educ Book 38:616-625. https://doi.org/10.1200/ EDBK 200689

20. Cheon H, Dziewulska KH, Moosic KB, Olson KC, Gru AA, Feith DJ, Loughran TP Jr (2020) Advances in the diagnosis and treatment of large granular lymphocytic leukemia. Curr Hematol Malig Rep 15:103-112. https://doi.org/10.1007/s11899-02000565-6

21. Morice WG, Kurtin PJ, Tefferi A, Hanson CA (2002) Distinct bone marrow findings in T-cell granular lymphocytic leukemia revealed by paraffin section immunoperoxidase stains for CD8, TIA-1, and granzyme B. Blood 99:268-274. https://doi. org/10.1182/blood.v99.1.268

22. Balint GP, Balint PV (2004) Felty's syndrome. Best Pract Res Clin Rheumatol 18:631-645. https://doi.org/10.1016/j. berh.2004.05.002

23. Koskela HL, Eldfors S, Ellonen P, van Adrichem AJ, Kuusanmäki $\mathrm{H}$, Andersson EI, Lagström S, Clemente MJ, Olson T, Jalkanen SE, Majumder MM, Almusa H, Edgren H, Lepistö M, Mattila P, Guinta K, Koistinen P, Kuittinen T, Penttinen K, Parsons A,
Knowles J, Saarela J, Wennerberg K, Kallioniemi O, Porkka K, Loughran TP Jr, Heckman CA, Maciejewski JP, Mustjoki S (2012) Somatic STAT3 mutations in large granular lymphocytic leukemia. N Engl J Med 366:1905-1913. https://doi.org/10.1056/ NEJMoa1114885

24. Jerez A, Clemente MJ, Makishima H, Koskela H, Leblanc F, Peng Ng K, Olson T, Przychodzen B, Afable M, Gomez-Segui I, Guinta K, Durkin L, Hsi ED, McGraw K, Zhang D, Wlodarski MW, Porkka K, Sekeres MA, List A, Mustjoki S, Loughran TP, Maciejewski JP (2012) STAT3 mutations unify the pathogenesis of chronic lymphoproliferative disorders of NK cells and T-cell large granular lymphocyte leukemia. Blood 120:3048-3057. https ://doi.org/10.1182/blood-2012-06-435297

25. Fasan A, Kern W, Grossmann V, Haferlach C, Haferlach T, Schnittger S (2013) STAT3 mutations are highly specific for large granular lymphocytic leukemia. Leukemia 27:1598-1600. https:// doi.org/10.1038/leu.2012.350

26. Shi M, He R, Feldman AL, Viswanatha DS, Jevremovic D, Chen D, Morice WG (2018) STAT3 mutation and its clinical and histopathologic correlation in T-cell large granular lymphocytic leukemia. Hum Pathol 73:74-81. https://doi.org/10.1016/j.humpa th.2017.12.014

27. Rajala HL, Eldfors S, Kuusanmäki H, van Adrichem AJ, Olson T, Lagström S, Andersson EI, Jerez A, Clemente MJ, Yan Y, Zhang D, Awwad A, Ellonen P, Kallioniemi O, Wennerberg K, Porkka K, Maciejewski JP, Loughran TP Jr, Heckman C, Mustjoki S (2013) Discovery of somatic STAT5b mutations in large granular lymphocytic leukemia. Blood 121:4541-4550. https:// doi.org/10.1182/blood-2012-12-474577

28. Aletaha D, Neogi T, Silman AJ, Funovits J, Felson DT, Bingham CO 3rd, Birnbaum NS, Burmester GR, Bykerk VP, Cohen MD, Combe B, Costenbader KH, Dougados M, Emery P, Ferraccioli G, Hazes JM, Hobbs K, Huizinga TW, Kavanaugh A, Kay J, Kvien TK, Laing T, Mease P, Ménard HA, Moreland LW, Naden RL, Pincus T, Smolen JS, Stanislawska-Biernat E, Symmons D, Tak PP, Upchurch KS, Vencovsky J, Wolfe F, Hawker G (2010) 2010 rheumatoid arthritis classification criteria: an American College of Rheumatology/European League Against Rheumatism collaborative initiative. Ann Rheum Dis 69:1580-1588. https://doi. org/10.1136/ard.2010.138461

29. van Dongen JJ, Langerak AW, Brüggemann M, Evans PA, Hummel M, Lavender FL, Delabesse E, Davi F, Schuuring E, GarcíaSanz R, van Krieken JH, Droese J, González D, Bastard C, White HE, Spaargaren M, González M, Parreira A, Smith JL, Morgan GJ, Kneba M, Macintyre EA (2003) Design and standardization of PCR primers and protocols for detection of clonal immunoglobulin and T-cell receptor gene recombinations in suspect lymphoproliferations: report of the BIOMED-2 Concerted Action BMH4CT98-3936. Leukemia 17:2257-2317. https://doi.org/10.1038/ sj.leu.2403202

30. Groenen PJTA, van Raaij A, van Altena MC, Rombout PM, Han van Krieken JM (2012) A practical approach to diagnostic Ig/ TCR clonality evaluation in clinical pathology. J Hematopathol 5:17-25. https://doi.org/10.1007/s12308-011-0131-7

31. Posnett DN, Sinha R, Kabak S, Russo C (1994) Clonal populations of $\mathrm{T}$ cells in normal elderly humans: the $\mathrm{T}$ cell equivalent to "benign monoclonal gammopathy." J Exp Med 179:609-618. https://doi.org/10.1084/jem.179.2.609

32. Delfau-Larue MH, Laroche L, Wechsler J, Lepage E, Lahet C, Asso-Bonnet M, Bagot M, Farcet JP (2000) Diagnostic value of dominant T-cell clones in peripheral blood in 363 patients presenting consecutively with a clinical suspicion of cutaneous lymphoma. Blood 96:2987-2992

33. Dippel E, Klemke D, Hummel M, Stein H, Goerdt S (2001) T-cell clonality of undetermined significance. Blood 98:247-248. https ://doi.org/10.1182/blood.v98.1.247 
34. Bigouret V, Hoffmann T, Arlettaz L, Villard J, Colonna M, Ticheli A, Gratwohl A, Samii K, Chapuis B, Rufer N, Roosnek E (2003) Monoclonal T-cell expansions in asymptomatic individuals and in patients with large granular leukemia consist of cytotoxic effector T cells expressing the activating CD94:NKG2C/E and NKD2D killer cell receptors. Blood 101:3198-3204. https://doi. org/10.1182/blood-2002-08-2408

35. Sidorova YV, Sychevskaya KA, Chernova NG, Julhakyan HL, Smirnova SJ, Ryzhikova NV, Gorodetskiy VR, Naumova EV, Sudarikov AB (2020) High incidence of clonal CD8+ T-cell proliferation in non-malignant conditions may reduce the significance of T-cell clonality assay for differential diagnosis in oncohematology. Clin Lymphoma Myeloma Leuk 20:203-208. https://doi. org/10.1016/j.clml.2019.12.021

36. Rajala HL, Porkka K, Maciejewski JP, Loughran TP Jr, Mustjoki $S$ (2014) Uncovering the pathogenesis of large granular lymphocytic leukemia-novel STAT3 and STAT5b mutations. Ann Med 46:114-122. https://doi.org/10.3109/07853890.2014.882105

37. Savola P, Brück O, Olson T, Kelkka T, Kauppi MJ, Kovanen PE, Kytölä S, Sokka-Isler T, Loughran TP, Leirisalo-Repo M,
Mustjoki S (2018) Somatic STAT3 mutations in Felty syndrome: an implication for a common pathogenesis with large granular lymphocyte leukemia. Haematologica 103:304-312. https://doi. org/10.3324/haematol.2017.175729

38. Prochorec-Sobieszek M, Chełstowska M, Rymkiewicz G, Majewski M, Warzocha K, Maryniak R (2008) Biclonal T-cell receptor gammadelta+ large granular lymphocyte leukemia associated with rheumatoid arthritis. Leuk Lymphoma 49:828-831. https://doi. org/10.1080/10428190801895337

39. Zhu Y, Gao Q, Hu J, Liu X, Guan D, Zhang F (2020) Clinical features and treatment outcomes in patients with T-cell large granular lymphocytic leukemia: a single-institution experience. Leuk Res 90:106299. https://doi.org/10.1016/j.leukres.2020.106299

Publisher's Note Springer Nature remains neutral with regard to jurisdictional claims in published maps and institutional affiliations.

\section{Affiliations}

\section{Vadim Romanovich Gorodetskiy ${ }^{1}$ (D) - Yulia Vladimirovna Sidorova ${ }^{2}$ (D) Natalia Alexandrovna Kupryshina ${ }^{3}$ (i)

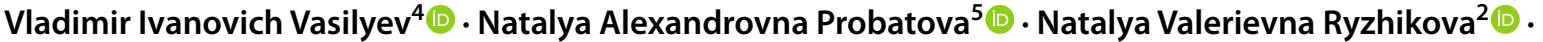 Andrey Borisovich Sudarikov ${ }^{2}[$}

Yulia Vladimirovna Sidorova iouliavl@gmail.com

Natalia Alexandrovna Kupryshina natalya-2511@yandex.ru

Vladimir Ivanovich Vasilyev vasilev.revmatolog@mail.ru

Natalya Alexandrovna Probatova probatova_na@mail.ru

Natalya Valerievna Ryzhikova nataly25-76@mail.ru

Andrey Borisovich Sudarikov dusha@blood.ru
1 Department of Intensive Methods of Therapy, V.A. Nasonova Research Institute of Rheumatology, Kashirskoye shosse 34A, Moscow 115522, Russia

2 Laboratory of Molecular Hematology, National Research Center for Hematology, Moscow, Russia

3 Hematopoiesis Immunology Laboratory, N.N. Blokhin Russian Cancer Research Center, Moscow, Russia

4 Diagnostic center of the MEDSI Clinic, Moscow, Russia

5 Department of Pathology, N.N. Blokhin Russian Cancer Research Center, Moscow, Russia 